\title{
The early phase of glucose-stimulated insulin secretion requires nitric oxide
}

\author{
G. A. Spinas ${ }^{1}$, R. Laffranchi ${ }^{1}$, I. Francoys ${ }^{1}$, I. David ${ }^{2}$, C. Richter ${ }^{3}$, M. Reinecke ${ }^{2}$ \\ ${ }^{1}$ Division of Endocrinology and Diabetes, Department of Internal Medicine, University Hospital, Zürich, Switzerland \\ ${ }^{2}$ Division of Neuroendocrinology, Institute of Anatomy, University of Zürich-Irchel, Zürich, Switzerland \\ ${ }^{3}$ Laboratory of Biochemistry I, Swiss Federal Institute of Technology (ETH), Zürich, Switzerland
}

Summary Nitric oxide (nitrogen monoxide, NO) acts as a signal transducer in a variety of cells. In the present study rat pancreatic islets were perifused with physiologically relevant glucose concentrations in the presence or absence of various NO-modulating agents. Perifusion in the presence of $0.1-1 \mathrm{mmol} / \mathrm{l}$ of the NO synthase inhibitor, $\mathrm{N}^{\mathrm{G}}$-monomethyl-L-arginine or of $10 \mu \mathrm{mol} / \mathrm{l}$ of the NO-scavenger, 2-(4-carboxyphenyl)-4,4,5,5-tetramethylimidazoline-1-oxyl-3oxide (carboxy-PTIO), resulted in an inhibition of the early phase of glucose-stimulated insulin secretion by $60-65 \%$ and $46 \%$, respectively. Light- and electron-microscopic studies revealed that pancreatic islets constitutively express NO-synthase in alpha and delta cells, where it is confined to the secretory granules. Therefore, these data indicate that NO may be important in the signal transduction pathway of the early phase of glucose-stimulated insulin secretion. [Diabetologia (1998) 41: 292-299]

Keywords Nitric oxide, nitrogen monoxide, insulin secretion, glucose, nitric oxide synthase, alpha cell, beta cell, delta cell.
Nitric oxide (nitrogen monoxide; NO) is an important messenger molecule in various cell types, e.g. endothelial cells [1], neurons [2], or T lymphocytes [3]. However, when produced in large amounts and over prolonged periods of time, e.g. by macrophages [4], NO is cytotoxic.

In pancreatic beta cells NO produced upon activation of the inducible isoform of NO synthase by cyto-

Received: 3 March 1997 and in revised form: 21 November 1997

Corresponding author: Dr. G. A.Spinas, Division of Endocrinology and Diabetes, Department of Internal Medicine, University Hospital, Rämistrasse 100, CH-8091 Zürich, Switzerland

Abbreviations: NO, Nitric oxide; NOS, NO synthase; LNMMA, N ${ }^{\mathrm{G}}$-Monomethyl-L-arginine; D-NMMA, NG-monomethyl-D-arginine; carboxy-PTIO, 2-(4-carboxyphenyl)4,4,5,5-tetramethylimidazoline-1-oxyl-3-oxide; FITC, fluorescein-isothiocyanate; AUC, area under the curve; L-NAME, $\mathrm{N}^{\mathrm{G}}$-nitro-L-arginine-methyl ester.

The first two authors contributed equally to the paper kines causes beta-cell destruction [5]. There is also evidence that NO could function as signal transmitter in beta cells. However, results obtained in pursuit of a possible involvement of NO in the signalling pathway of insulin secretion are controversial. Some investigations provided evidence that NO, presumably produced by a calcium/calmodulin-dependent constitutive NO synthase (NOS), participates in the signal transduction pathway mediating insulin secretion [6], and that L-arginine-derived NO mediates insulin secretion via stimulation of guanylate cyclase and cGMP formation [7]. Others found no evidence for endogenously produced $\mathrm{NO}$ being involved in the initiation of secretagogue-induced insulin release [8] or reported that L-arginine-derived NO may even inhibit insulin release [9].

Recently, Willmott et al. [10] showed that beta cells preloaded with tryptamine, which accumulates in insulin-containing granules and is co-secreted with insulin, respond to $\mathrm{NO}$ by mobilizing $\mathrm{Ca}^{2+}$ from the endoplasmic reticulum accompanied by a release of tryptamine from the cells. These data corroborate our previous finding that exogenously added NO 
stimulates insulin secretion from INS-1 cells by inducing calcium release from mitochondria [11].

The site of NO production, mainly analysed by the immunohistochemical localization of NOS, in the pancreatic islets has not yet been identified. According to some authors NOS is present in all islet cells $[6,12]$ while others failed to detect NOS immunoreactivity in pancreatic islets and beta cells [13-15]. Therefore, our study also aimed to analyse the location of NOS in the isolated rat islet model.

In the present study we provide evidence that the immediate glucose-induced insulin secretion from pancreatic islets requires the formation of $\mathrm{NO}$, and that NO may be formed by a constitutively expressed NOS located in the vascular endothelium and islet alpha- and delta-cells.

\section{Materials and methods}

Materials. Collagenase A from Clostridium histolyticum was purchased from Boehringer Mannheim (Rotkreuz, Switzerland); culture medium RPMI-1640 and newborn calf serum (NCS) were from Gibco (Basel, Switzerland); rat insulin was from Novo Nordisk (Bagsvaerd, Denmark). $\mathrm{N}^{\mathrm{G}}$-MonomethylL-arginine (L-NMMA), $\quad \mathrm{N}^{\mathrm{G}}$-monomethyl-D-arginine (DNMMA) and 2-(4-carboxyphenyl)-4,4,5,5-tetramethylimidazoline-1-oxyl-3-oxide (carboxy-PTIO) were from Calbiochem (Luzern, Switzerland).

For immunohistochemistry the following antisera were used: antiserum SA-201 (Lot No: T3103; Biomol; Plymouth Meeting Penn., USA) raised in rabbit against endothelial NOS (eNOS); antiserum A 564 against insulin (Dako, Copenhagen, Denmark); antiserum 017060 against glucagon (Bioscience, Emmenbrücke, Switzerland); antiserum NT 116 against somatostatin (Eugene Tech, New Jersey, USA); antiserum 615-R110-146-6 against pancreatic polypeptide (Dr. R. Chance, Indianapolis, Ind., USA). For detailed information on the antisera see Reference [16].

All other chemicals were of the highest purity commercially available.

Islet isolation and culture. Rat islets were isolated from collagenase-treated pancreata of newborn male and female (4-5 days old) Zur:SD rats and precultured in RPMI-1640 (containing $11 \mathrm{mmol} / \mathrm{l}$ glucose) $+10 \%$ NCS. After 4 days, islets were washed and cultured for 2 days in RPMI- $1640+1 \mathrm{mg} / \mathrm{ml} \mathrm{hu-}$ man serum albumin.

Perifusion protocol. Batches of 50 islets were placed in a perifusion chamber with a volume of $300 \mu$ land perifused with Krebs-Ringer buffer at a flow rate of $600 \mu \mathrm{l}$ per min.

During the first $49 \mathrm{~min}$ islets were perifused with $1.6 \mathrm{mmol} /$ 1 glucose. From min 49 to 59 the test substance was added to the perifusion medium (e.g. L-NMMA). At min 59 the glucose concentration was raised to $16 \mathrm{mmol} / \mathrm{l}$ for a period of $40 \mathrm{~min}$ (min 59-99), with the test substance still present. Thereafter (min 99-106), the glucose concentration was again lowered to $1.6 \mathrm{mmol} / \mathrm{l}$. Fractions of the perifusate were collected each minute for determination of insulin. Insulin was measured with a competitive ELISA technique using rat insulin as standard $[17,18]$. The detection limit was $0.1 \mathrm{ng} / \mathrm{ml}$. The intraand interassay coefficient of variation was 6 and $9 \%$, respectively.
Immunohistochemical studies. Rat islets isolated as described above were fixed in a solution containing freshly made $2.5 \%$ paraformaldehyde, $0.1 \%$ glutardialdehyde and $0.01 \%$ picric acid for about $4 \mathrm{~h}$ at room temperature. Thereafter, specimens were dehydrated in an ascending series of ethanol and routinely embedded in LR White (Polysciences, Warrington, PA., USA).

Light microscopy: Semithin sections $(1.5 \mu \mathrm{m})$ were cut with a Reichert-Jung Ultracut E (Reichert-Jung, Zürich, Switzerland) and treated with phosphate-buffered saline containing $2 \%$ bovine serum albumin and $2 \%$ normal goat serum to reduce unspecific binding. For analysis of the coexistence of classical islet hormones and NOS, four consecutive sections were incubated consecutively for double immunofluorescence: the first section was incubated with the rabbit pancreatic polypeptide-antiserum, the second with the rabbit eNOS-antiserum (SA-201) and with the guinea pig insulin-antiserum, the third with the eNOS-antiserum and the mouse glucagon-antiserum, and the fourth with the eNOS-antiserum and the rat somatostatin-antiserum. Incubations were carried out for $12 \mathrm{~h}$ at $4{ }^{\circ} \mathrm{C}$. After buffer wash, the following secondary antisera were applied: biotinylated sheep anti-mouse IgG (Amersham International, Amersham, UK, $1: 100$ ) for the mouse glucagon-antiserum, biotinylated goat anti-guinea pig IgG (Bioscience Products, Emmenbrücke, Switzerland; $1: 100)$ for the insulinantiserum and biotinylated sheep anti-rat IgG (Amersham, $1: 100)$ for the rat somatostatin antiserum. Visualization was obtained with streptavidin-Texas-Red (Amersham, 1:50). For the detection and visualization of the rabbit antisera against eNOS and pancreatic polypeptide, fluorescein-isothiocyanate (FITC)-conjugated goat anti-rabbit IgG (Bioscience Products, $1: 40$ ) was used. Photomicrographs were taken with a Zeiss Axiophot (Zeiss, Zürich, Switzerland). For photography, the fluorochromes were visualized with fluorescence modules for FITC (BP 450-490 nm, FT 510, LP 515-565 nm) and for Texas-Red (BP 546, FT 580, LP $590 \mathrm{~nm}$ ). Examination of co-existence was mainly carried out using a FITC/Texas-Red module (BP 485/20 546/12, FT 500/560, LP 515-530/580-630).

Electron microscopy: Ultrathin sections were cut with a Reichert-Jung Ultracut E. Sections were treated with $50 \mu \mathrm{mol} / 1$ gelatine in $10 \mathrm{ml}$ phosphate buffered saline (PBS) containing $0.2 \mathrm{~g}$ bovine serum albumin and rinsed in PBS. For single staining, sections were incubated with antiserum SA-201 (1:500) overnight. After repetitive washing in PBS, anti-rabbit biotin $(1: 50)$ was applied to the sections for $1 \mathrm{~h}$ at room temperature. After washing in PBS, a $10 \mathrm{~nm}$ sized streptavidin-gold complex (1:50, Amersham was applied for $3 \mathrm{~h}$ at room temperature. For double staining, sections were incubated with NOS-antisera $(1: 200)$ and the mouse glucagon-antiserum $(1: 700)$. After repetitive washing in PBS, anti-mouse biotin labelled with $5 \mathrm{~nm}$ sized gold particles $(1: 25)$ and anti-rabbit biotin $(1: 25)$ were applied to the sections for $1 \mathrm{~h}$ at room temperature. After washing in PBS, a $15 \mathrm{~nm}$ sized streptavidingold complex (1:50, Amersham) was applied for $1 \mathrm{~h}$ at room temperature. Sections were rinsed in distilled water, air-dried and counterstained with uranyl acetate for $4 \mathrm{~min}$. Sections were examined with a Philips EM 420 electron microscope.

Specificity controls: The specificity of the reactions obtained was tested using the following controls: 1) replacement of the primary antiserum by pre-immune or non-immune serum. 2) Preabsorption of the primary antisera with homologous and heterologous antigens at $5-500 \mu \mathrm{g} / \mathrm{ml}$ of antiserum.

Preabsorption of antiserum SA-201 with synthetic eNOS at a concentration of $10 \mu \mathrm{g} / \mathrm{ml}$ completely abolished staining. In 

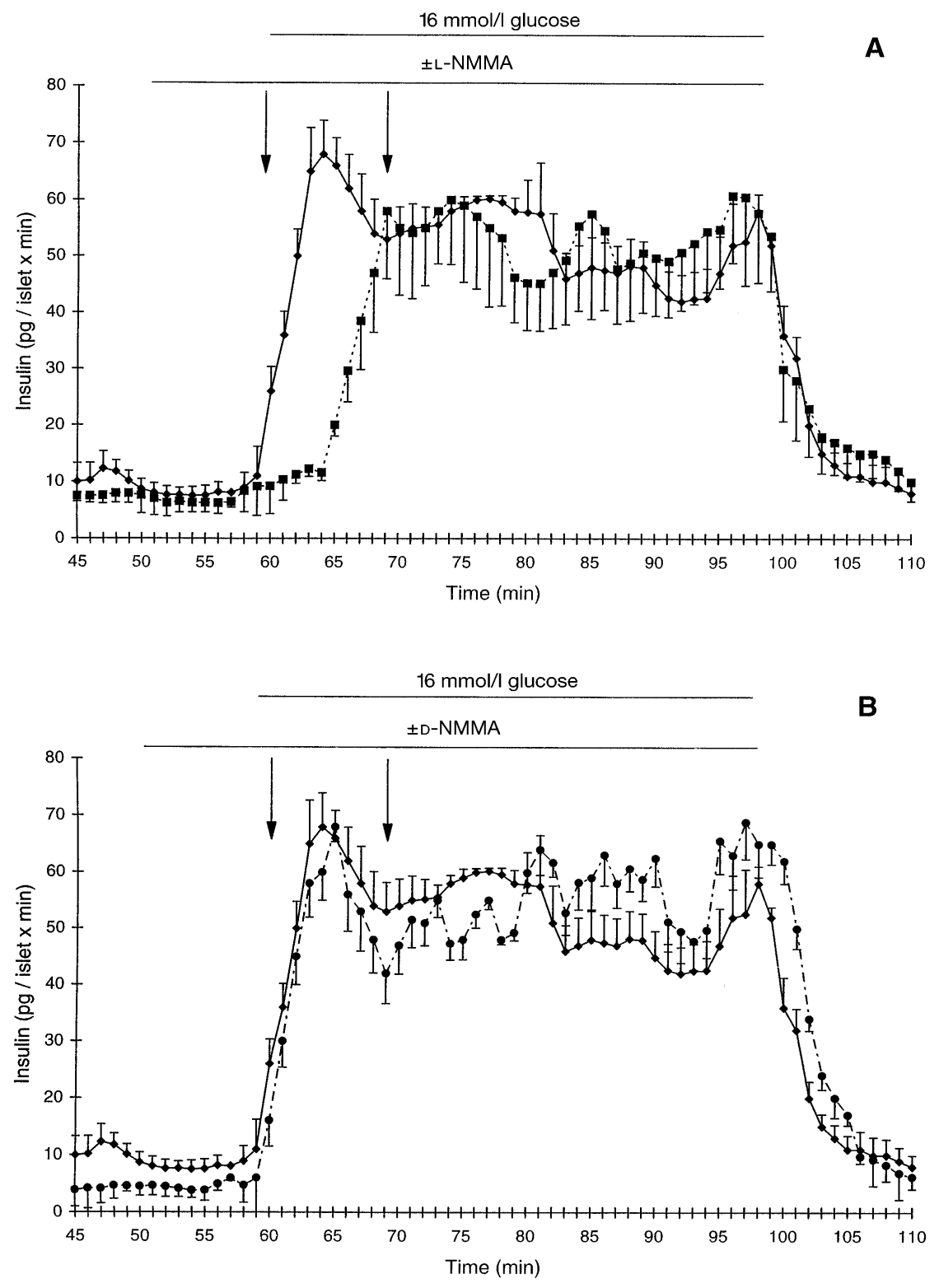

Fig. 1. A, B Effects of L-NMMA (A) and D-NMMA (B) on glucose-stimulated insulin secretion. Islets were perifused as described in Materials and methods. L-NMMA and D-NMMA were applied at a concentration of $0.5 \mathrm{mmol} / \mathrm{l}$. Data are means \pm SEM of 5 experiments. Arrows denote the beginning and end of the first phase. Traces show control $(\bullet), \mathrm{L}-$ NMMA- ( $\bullet$ ) and D-NMMA-exposed ( $\bullet$ ) islets, respectively

contrast, preabsorption of antiserum SA-201 with synthetic glucagon or somatostatin did not influence immunoreactions. Reactions obtained by the antisera against the islet hormones could be abolished only by preabsorption with the respective antigen $(10 \mu \mathrm{g} / \mathrm{ml})$, but were still present after preabsorption with synthetic eNOS at concentrations as high as $500 \mu \mathrm{g} / \mathrm{ml}$.

Morphometric analysis: Two independent observers blinded to the protocol evaluated both distribution and intensity of NOSimmunoreactivity in the 28 islets investigated by double immunofluorescence.
At the subcellular level, quantitative morphometry was performed additionally. Two independent observers blinded to the protocol counted the NOS-immunogold grains in the following areas: secretory granules, extragranular cell compartment and extracellular space. The procedure was applied for alpha-, beta-, delta- and PP-cells as well for endothelial cells. Countings were carried out on prints at a magnification of 23000 using a transparent sheet with $1 \mathrm{~nm}^{2}$ squares.

Statistical analysis. Only perifusion experiments with islets from different isolations were considered as separate experiments. The areas under the curve (AUC) for the first and the second phase were compared separately. For calculation the first phase was defined from the earliest time point with an increased insulin secretion after the glucose stimulus until the time point with the lowest insulin level after the first peak. Thereafter, the second phase commenced lasting until the end of the glucose stimulation. In the figures, the beginning and the end of the first phase are marked with arrows. Data were analysed using the Wilcoxon matched pairs test. $P$ less than 0.05 was considered significant. 


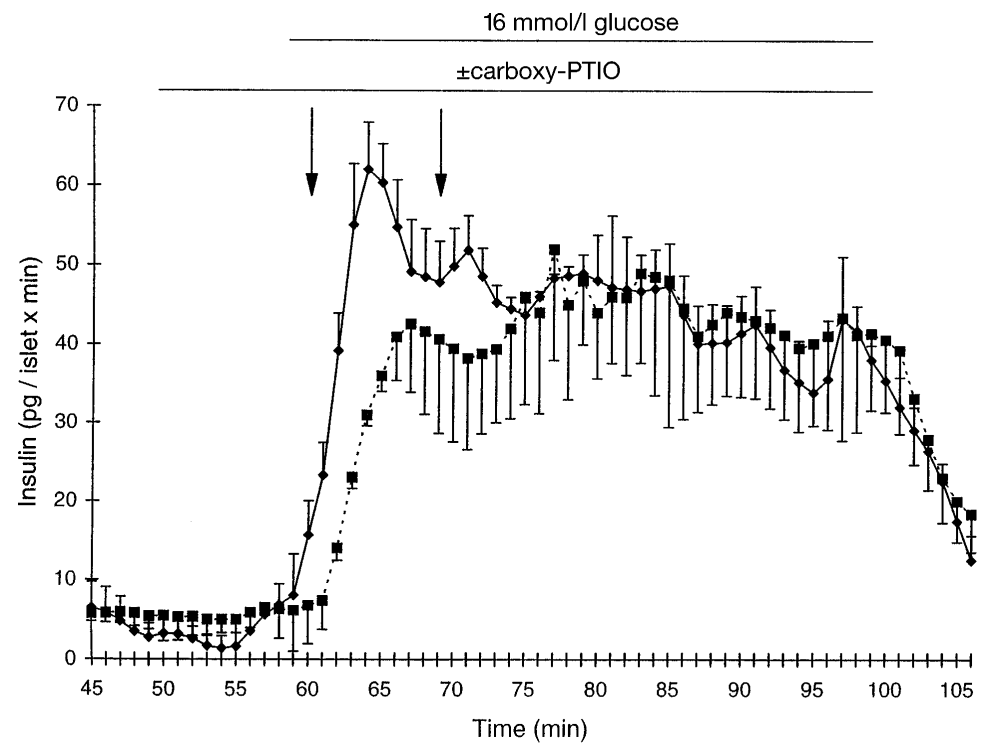

Fig. 2. Inhibition of glucose-stimulated insulin secretion by carboxy-PTIO. Islets were perifused as described in Materials and methods. Carboxy-PTIO was applied at a concentration of $10 \mathrm{mmol} / \mathrm{l}$. Data are means \pm SEM of 5 experiments. Arrows denote the beginning and end of the first phase. Traces show control $(\diamond)$ and carboxy-PTIO-exposed $(\boldsymbol{\square})$ islets, respectively

Table 1. Inhibition of the first phase of insulin secretion by various concentrations of $\mathrm{L}-\mathrm{NMMA}$

\begin{tabular}{ll}
\hline L-NMMA $(\mathrm{mmol} / \mathrm{l})$ & $\%$ inhibition of insulin secretion \\
\hline 0.1 & $65 \pm 15^{\mathrm{a}}$ \\
0.5 & $62 \pm 10^{\mathrm{a}}$ \\
1 & $60 \pm 17^{\mathrm{a}}$ \\
5 & $30 \pm 20$
\end{tabular}

Data are man \pm SEM of five experiments. ${ }^{a} p<0.05$ vs control (0\% inhibition)

Table 2. Distribution patterns and intensity of NOS-immunofluorescence in 28 rat islets

\begin{tabular}{lllll}
\hline & $\begin{array}{l}\text { Alpha cell } \\
(n=968)\end{array}$ & $\begin{array}{l}\text { Beta cell } \\
(n=1262)\end{array}$ & $\begin{array}{l}\text { Delta cell } \\
(n=314)\end{array}$ & $\begin{array}{l}\text { PP cell } \\
(n=163)\end{array}$ \\
\hline $\begin{array}{l}\text { Intensity } \\
\begin{array}{l}\text { Percentage of } \\
\text { reacting cells }\end{array}\end{array}$ & +++ & - & $+/++$ & - \\
\hline
\end{tabular}

Data are mean \pm SEM

Islets were analysed as described in Materials and Methods

\section{Results}

Perifusion studies. Rat islets perifused with buffer containing $1.6 \mathrm{mmol} / \mathrm{l}$ glucose secrete little insulin, i. e. $5-10 \mathrm{pg} /$ islet $\times$ min. Increasing the ambient glucose concentration from 1.6 to $16 \mathrm{mmol} / \mathrm{l}$ results in a typical biphasic pattern of insulin secretion (Fig.1). The first phase starts roughly 2 min after the increase of the glucose concentration and lasts for approxi- mately $9 \mathrm{~min}$. The second phase is characterized by a sustained insulin release with slow oscillations with a frequency of 7 to $10 \mathrm{~min}$.

The NOS inhibitor, L-NMMA [19], at a concentration of $0.5 \mathrm{mmol} / \mathrm{l}$ had no influence on insulin secretion at low ambient glucose, but markedly (by $62 \%$ ) inhibited the first phase of high glucose-stimulated insulin secretion (Fig.1A). Thus, the AUC for the first phase was $42.9 \pm 3.7 \mathrm{pg} /$ islet $\times \min$ and $16.3 \pm$ $3.1 \mathrm{pg} /$ islet $\times$ min in controls and L-NMMA-exposed islets, respectively $(p<0.05)$. The second phase was not altered by L-NMMA, the AUC being $44.6 \pm$ $3.9 \mathrm{pg} /$ islet $\times$ min and $46.1 \pm 8.6 \mathrm{pg} /$ islet $\times$ min in controls and L-NMMA-exposed islets, respectively.

The enantiomer D-NMMA, which does not inhibit NOS [20], was used as control. As shown in Figure $1 \mathrm{~B}, 0.5 \mathrm{mmol} / \mathrm{l} \mathrm{D}-\mathrm{NMMA}$ had no effect on insulin secretion, the AUC for the first phase being $42.9 \pm$ $3.7 \mathrm{pg} /$ islet $\times$ min and $39.8 \pm 2.1 \mathrm{pg} /$ islet $\times$ min in controls and D-NMMA-treated islets, respectively, and for the second phase $44.6 \pm 3.0 \mathrm{pg} /$ islet $\times \min$ and $52.3 \pm 4.5 \mathrm{pg} /$ islet $\times$ min controls and D-NMMAtreated islets, respectively.

Significant inhibition of the first phase of insulin secretion was achieved with L-NMMA concentrations of $0.1-1 \mathrm{mmol} / \mathrm{l}$ (Table 1 ), while $5 \mathrm{mmol} / \mathrm{l} \mathrm{had}$ no inhibitory effect. Addition of $10 \mu \mathrm{mol} / 1$ carboxyPTIO, an NO scavenger [21], to the perifusion medium resulted in an inhibition by $46 \%$ of the first phase of insulin secretion (Fig.2). The AUC was $42.5 \pm$ $6.9 \mathrm{pg} /$ islet $\times$ min and $23.3 \pm 5.1 \mathrm{pg} /$ islet $\times$ min in controls and carboxy-PTIO-exposed islets, respectively $(p<0.05)$. The second phase was not affected, the AUC being $40.7 \pm 8.3 \mathrm{pg} /$ islet $\times \min$ and $38.4 \pm$ $12.4 \mathrm{pg} /$ islet $\times$ min in controls and carboxy-PTIO-exposed islets, respectively.

Immunohistochemistry. We subjected 28 islets from 4 different isolates to light-microscopical and 8 islets 

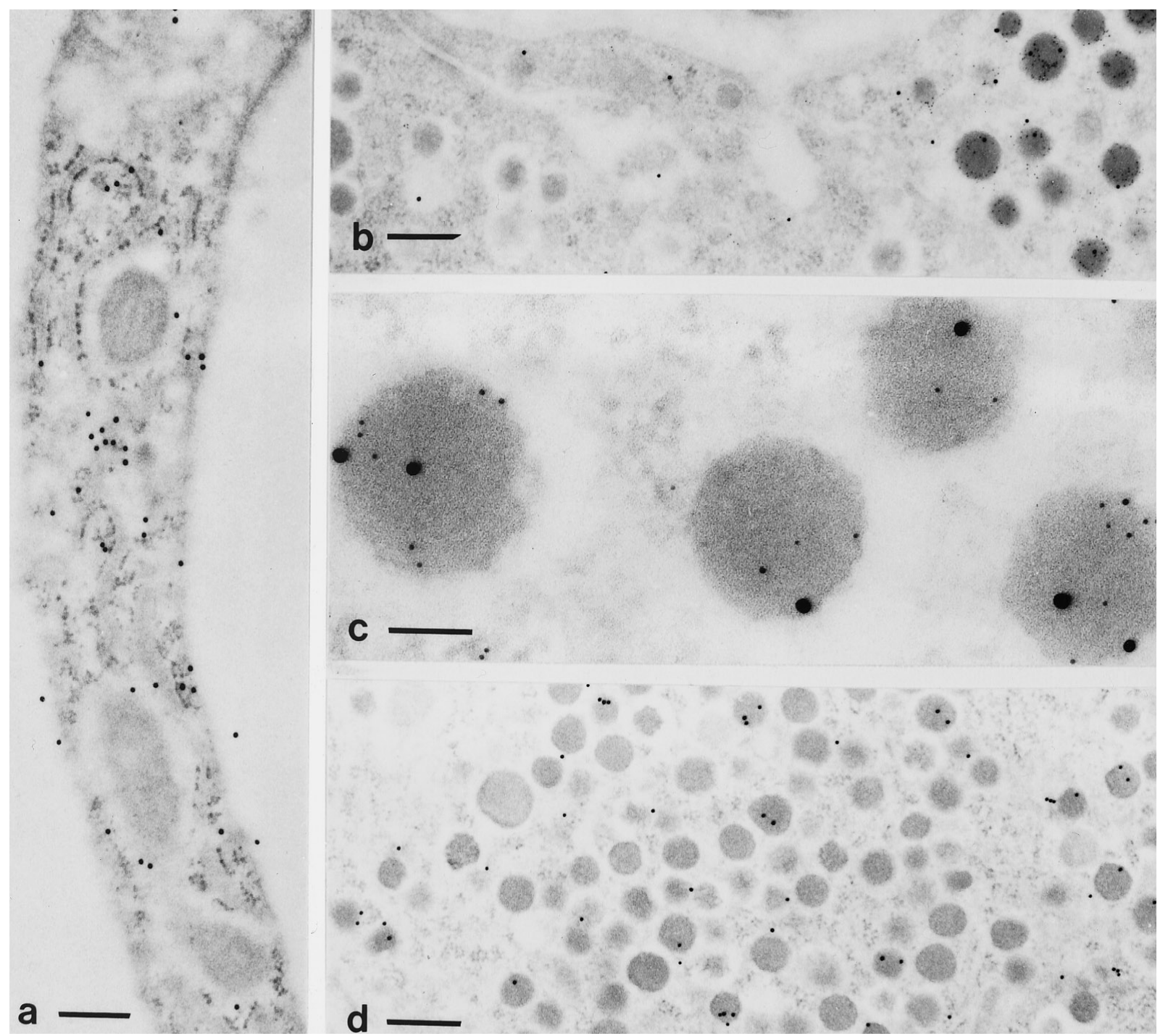

Fig.3a-d. Subcellular localization of NOS-immunoreactivity in cells of isolated rat islets. a. Immunogold labelling is found throughout the cytoplasm of the vascular endothelial cell. Scale bar: $0.7 \mu \mathrm{m}$. b. No labelling occurs in the beta cells on the left side, whereas the secretory granules of the alpha cell on the right side contain NOS-immunoreactivity (large gold particles). The alpha cell is identified by its glucagon-immunoreactivity (small gold particles). Scale bar: $2 \mu \mathrm{m}$. c. Higher magnification of alpha cell granules. The secretory granules exhibit both labelling by small gold particles, i.e. glucagon-immunoreactivity, and large gold particles, i.e. NOS-immunoreactivity. Scale bar: $0.2 \mu \mathrm{m}$. d. Part of a delta cell. NOS-immunoreactivity is present in several secretory granules. Scale bar: $1 \mu \mathrm{m}$

to electron-microscopical immunohistochemistry. NOS-immunoreactivity was observed in all islets investigated and was located in cells of the vascular endothelium and in islet cells. In the electron-microscope, the endothelial cells showed immunogold labelling dispersed over the cytoplasm (Fig.3). NOSimmunoreactive islet cells were mainly at the islet pe- riphery (Fig.4) but occasionally also randomly distributed throughout the islets. NOS-immunoreactivity was mainly found in the alpha-, i.e. glucagon-immunoreactive cells (Figs. 3 and 4) and in the delta-, i.e. somatostatin-immunoreactive cells (Fig.4) but not in beta-, i. e. insulin-immunoreactive cells. In all islets investigated NOS-immunoreactive alpha- and delta-cells were present although their relative numbers varied among the islets. The percentage of alpha- and delta-cells containing NOS-immunoreactivity ranged from 20 to $100 \%$ with an average of $65 \%$ (alpha-cells) and 76\% (delta-cells), respectively (Table 2). At the subcellular level, NOS-immunoreactivity was confined to the secretory granules of both alpha- and delta-cells (Fig. 3, Table 3) and in the cytoplasm of endothelial cells. The faint immunogold staining observed in the granules of some beta and PP cells as well as in the extragranular cell compartment (Table 3) most likely represents background reactivity but may also reflect sensitivity differences between immunofluorescence and the immunogold technique. 

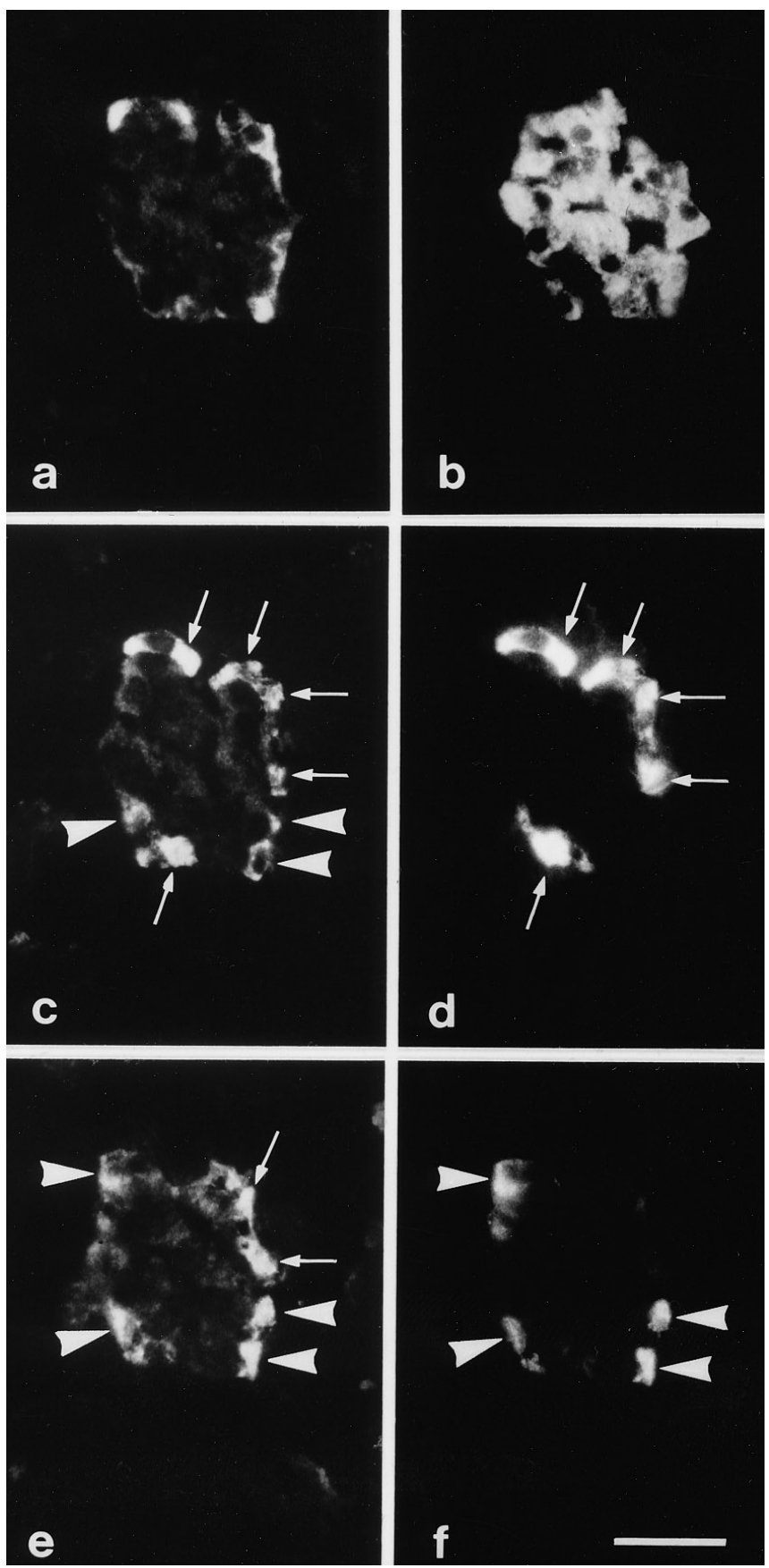

Fig. 4a-f. Localization of NOS-immunoreactivity in isolated rat islets as revealed by double immunofluorescence of NOS (a) and insulin (b), NOS (c) and glucagon (d) and NOS (e) and somatostatin $\mathbf{f}$ on three consecutive semithin sections. a,b. NOS- and insulin-immunoreactivities are present in different subpopulations of islet cells. c,d. Partial co-existence of NOS- and glucagon-immunoreactivities (arrows). e,f. NOS-immunoreactivity in somatostatin-immunoreactive cells (arrowheads). Scale bar $20 \mu \mathrm{m}$

\section{Discussion}

Perifusion of rat islets with the NOS inhibitor LNMMA, but not with its inactive enantiomer DNMMA acutely inhibits the early phase of glucose- stimulated insulin release, the maximal inhibition being observed with concentrations of $0.1-1 \mathrm{mmol} / \mathrm{l}$ of L-NMMA. Inhibition is also achieved with the NOscavenger carboxy-PTIO. These findings provide compelling evidence that NO is involved in the regulation of the early phase of glucose-stimulated insulin secretion and support the notion that NO plays a role in the secretagogue-induced signal transduction in rat pancreatic islets.

Our findings corroborate some previously published data. Schmidt and co-workers [6] found with HIT cells that L-arginine-induced insulin release in the presence of glucose is partly mediated by NO. Laychock et al. [7] incubated isolated rat islets for 20 min with L-NMMA and demonstrated that glucose- and L-arginine-stimulated insulin release depends partly on the endogenous formation of $\mathrm{NO}$ and cGMP. Furthermore, continuous infusion of glucose together with a NOS inhibitor into conscious calves resulted in reduced plasma insulin and elevated plasma glucose concentration [22].

However, a number of studies seem to argue against a stimulatory effect of NO on insulin secretion. Thus, incubation of islets for $30 \mathrm{~min}$ with an NOS inhibitor did not result in a detectable inhibition of insulin release [8]. Since in these experiments accumulated insulin was measured possible changes of the early insulin secretory phase may have been masked. In anaesthetized rats [23] or with chronic administration of $\mathrm{N}^{\mathrm{G}}$-nitro-L-arginine-methyl ester ( $\mathrm{L}$ NAME) to rats [24] no significant effects of NOS inhibition on insulin release could be observed. Similarly, perfusion of rat pancreata with $5 \mathrm{mmol} / \mathrm{l} \mathrm{L}$ NAME had no effect on insulin secretion, while on the other hand perfusion with $5 \mathrm{mmol} / \mathrm{l}$ L-NMMA resulted in increased insulin levels [25]. These experiments are, however, difficult to compare with our perifusion system since in vivo administration or pancreas perfusion with NOS inhibitors may exert additional systemic effects such as vasoconstriction [23] or interfere with neuronal mechanisms which could affect insulin release [26]. Furthermore, NOS inhibition may also cause an increase in islet capillary blood flow [27].

Recent studies suggest that L-arginine-derived NO may even suppress insulin release, since addition of LNAME to the incubation medium resulted in an increase of insulin release [12, 28, 29]. However, in these studies a very high concentration of L-NAME ( $5 \mathrm{mmol} / \mathrm{l})$ was used. According to Drews et al. [30] such a high concentration of L-NAME depolarizes the beta cell similarly to L-arginine and may trigger insulin release. Such an effect could explain why also in the present study $5 \mathrm{mmol} / \mathrm{l}$ of L-NMMA did not inhibit glucose-induced insulin secretion any longer. A severely impaired glucose-induced insulin secretory capacity was also observed after a $48 \mathrm{~h}$ exposure of rat islets to $4.5 \mathrm{mmol} / \mathrm{l}$ aminoguanidine, another 
Table 3. Number of NOS-immunoreactive gold particles per $1 \mathrm{~nm}^{2}$

\begin{tabular}{llllll}
\hline & Alpha cells & Beta cells & Delta cells & PP-cells & Endothelial cells \\
\hline $\begin{array}{l}\text { Secretory granules } \\
\text { Squares counted }\end{array}$ & $0.67 \pm 0.87$ & $0.06 \pm 0.23$ & $0.26 \pm 0.044$ & $0.04 \pm 0.19$ & $\mathrm{NE}$ \\
Extragranular cell & 123 & 125 & 93 & 17 & $\mathrm{NE}$ \\
compartment & $0.06 \pm 0.24$ & $0.08 \pm 0.39$ & $0.04 \pm 0.20$ & $0.05 \pm 0.28$ & $0.43 \pm 0.28$ \\
Squares counted & 307 & 154 & 176 & 39 & 71 \\
Extracellular space & $0.02 \pm 0.16$ & $0.01 \pm 0.11$ & $0.01 \pm 0.12$ & $0.02 \pm 0.18$ & $0.02 \pm 0.17$ \\
Squares counted & 43 & 76 & 22 & 14 & 43 \\
\hline
\end{tabular}

Data are mean \pm SEM

NE, Non-existent

Islets were analysed as described in Materials and Methods

NOS inhibitor [31]. At this concentration aminoguanidine may be toxic to pancreatic islets [31].

The demonstration that endogenously produced NO participates in the signal transduction pathway of insulin secretion warrants the search for the presence of NO producing cells within the islets. Whether pancreatic islets, particularly the endocrine islets, constitutively express NOS is still a matter of discussion. Some investigators described NOS-immunoreactivity and/or NADPH-diaphorase staining in the majority of rat and mouse islet cells $[6,12]$, whereas others failed to detect NOS-immunoreactivity in human and rat islets [13-15]. Apart from the important influence of the fixation procedures used $[14,15]$ and species differences, the existence of local isoforms of NOS may account for the observed discrepancies [15].

The present study confirms the presence of NOSimmunoreactivity in the endocrine pancreas. The NOS-immunoreactivity, as assessed by immunofluorescence was confined to alpha cells and some delta cells and was not detectable in beta cells, while with the immunogold technique faint staining was also observed in some beta and PP cells. The finding that delta cells constitutively express NOS is an accordance with recent data obtained with murine and human pancreases [32]. To our knowledge, the presence of NOS in alpha cells has not been reported so far.

Our immunocytochemical studies demonstrating that NOS-immunoreactivity is mainly confined to the secretory granules of alpha and delta cells, represent the first ultrastructural localization of the enzyme in cells of the endocrine pancreas. The subcellular localization of NOS in endocrine islet cells is in accordance with recent reports describing NOS in secretory granules of gastric D-cells [32] and in synaptic vesicles of enteric neurons [33].

The presence of NOS-immunoreactivity in the secretory granules may indicate the production and subsequent diffusion of NO from alpha and delta cells to beta cells. The effects of NO on glucose-stimulated insulin release from beta cells under physiological conditions could, therefore, be exerted in a paracrine manner by neighbouring alpha and/or delta cells or by endothelial cells. However, since we only looked for eNOS-immunoreactivity we cannot exclude that other isoforms of the enzyme, e.g. nNOS or iNOS may be expressed in the beta cells themselves. Further studies including Western blot analysis and assessment of enzyme activity in different islet cell types are needed, particularly since faint immunogold staining for NOS was also seen in some beta and PP cells.

The mechanism by which NO triggers insulin release remains to be elucidated. There are different possibilities which warrant further investigation: NO could mobilize $\mathrm{Ca}^{2+}$ from the endoplasmic reticulum as recently demonstrated in sea urchin eggs by Willmott et al. [34] or from the mitochondrial $\mathrm{Ca}^{2+}$ pool $[11,35]$. Another possible target for NO could be the insulin vesicle, since in synaptosomes NO modulates synaptic vesicle docking fusion reactions [36]. Finally, NO could interact with some receptors on the beta cell surface or with ion channels as was suggested for neurons [37-41].

In summary, the data presented here show that the early phase of glucose-stimulated insulin secretion is at least partly mediated by NO which could be produced in islet alpha and delta cells.

Acknowledgements. We thank Dr. W. Pralong for helpful discussions, and Y. Glatz for skillful technical assistance.

\section{References}

1. Ignarro LJ (1990) Biosynthesis and metabolism of endothelium-derived nitric oxide. Annu Rev Pharmacol Toxicol 30: $535-560$

2. Snyder SH (1992) Nitric oxide: first in a new class of neurotransmitters. Science 257: 494-496

3. Kirk SJ, Regan MC, Barbul A (1990) Cloned murine T lymphocytes synthesize a molecule with the biological characteristics of nitric oxide. Biochem Biophys Res Commun 173: 660-665

4. Marletta MA, Yoon PS, Iyengar R, Leaf CD, Wishnok JS (1988) Macrophage oxidation of L-arginine to nitrite and nitrate: nitric oxide is an intermediate. Biochemistry 27 : 8706-8711

5. Corbett JA, Sweetland MA, Wang JL, Lancaster JR, Jr., McDaniel ML (1993) Nitric oxide mediates cytokine-induced inhibition of insulin secretion by human islets of Langerhans. Proc Natl Acad Sci U S A 90: 1731-1735 
6. Schmidt HH, Warner TD, Ishii K, Sheng H, Murad F (1992) Insulin secretion from pancreatic B cells caused by L-arginine-derived nitrogen oxides. Science 255: 721-723

7. Laychock SG, Modica ME, Cavanaugh CT (1991) L-arginine stimulates cyclic guanosine $3^{\prime}, 5^{\prime}$-monophosphate formation in rat islets of Langerhans and RINm5F insulinoma cells: evidence for L-arginine : nitric oxide synthase. Endocrinology 129: 3043-3052

8. Jones PM, Persaud SJ, Bjaaland T, Pearson JD, Howell SL (1992) Nitric oxide is not involved in the initiation of insulin secretion from rat islets of Langerhans. Diabetologia 35: 1020-1027

9. Panagiotidis G, Akesson B, Rydell EL, Lundquist I (1995) Influence of nitric oxide synthase inhibition, nitric oxide and hydroperoxide on insulin release induced by various secretagogues. Br J Pharmacol 114: 289-296

10. Willmott NJ, Galione A, Smith PA (1995) Nitric oxide induces intracellular $\mathrm{Ca}^{2+}$ mobilization and increases secretion of incorporated 5-hydroxytryptamine in rat pancreatic beta-cells. FEBS Lett 371: 99-104

11. Laffranchi R, Gogvadze V, Richter C, Spinas GA (1995) Nitric oxide (nitrogen monoxide, NO) stimulates insulin secretion by inducing calcium release from mitochondria. Biochem Biophys Res Commun 217: 584-591

12. Panagiotidis G, Akesson B, Alm P, Lundquist I (1994) The nitric oxide system in the endocrine pancreas induces differential effects on the secretion of insulin and glucagon. Endocrine 2: 787-792

13. Shimosegawa T, Abe T, Satoh A, et al. (1992) Histochemical demonstration of NADPH-diaphorase activity, a marker for nitric oxide synthase, in neurons of the rat pancreas. Neurosci Lett 148: 67-70

14. Vincent SR (1992) Nitric oxide and arginine-evoked insulin secretion. Science 258: 1376-1378

15. Worl J, Wiesand M, Mayer B, Greskotter KR, Neuhuber WL (1994) Neuronal and endothelial nitric oxide synthase immunoreactivity and NADPH-diaphorase staining in rat and human pancreas: influence of fixation. Histochemistry 102: 353-364

16. Maake C, Reinecke M (1993) Immunohistochemical localization of insulin-like growth factor 1 and 2 in the endocrine pancreas of rat, dog, and man, and their coexistence with classical islet hormones. Cell Tissue Res 273: 249-259

17. Kekow J, Ulrichs K, Muller Ruchholtz W, Gross WL (1988) Measurement of rat insulin. Enzyme-linked immunosorbent assay with increased sensitivity, high accuracy, and greater practicability than established radioimmunoassay. Diabetes 37: 321-326

18. Webster HV, Bone AJ, Webster KA, Wilkin TJ (1990) Comparison of an enzyme-linked immunosorbent assay (ELISA) with a radioimmunoassay (RIA) for the measurement of rat insulin. J Immunol Methods 134: 95-100

19. Sakuma I, Stuehr DJ, Gross SS, Nathan C, Levi R (1988) Identification of arginine as a precursor of endothelium-derived relaxing factor. Proc Natl Acad Sci USA 85: 8664-8667

20. Rees DD, Palmer RM, Schulz R, Hodson HF, Moncada S (1990) Characterization of three inhibitors of endothelial nitric oxide synthase in vitro and in vivo. $\mathrm{Br} \mathrm{J}$ Pharmacol 101: 746-752

21. Akaike T, Yoshida M, Miyamoto Y, et al. (1993) Antagonistic action of imidazolineoxyl $\mathrm{N}$-oxides against endothelium-derived relaxing factor NO through a radical reaction. Biochemistry 32: 827-832

22. Edwards AV, Ghatei MA, Bloom SR (1994) Nitric oxiderelated pancreatic endocrine responses to hyperglycaemia in the conscious calf. Experientia 50: 725-726
23. Jun T, Sakinis A, Wennmalm A (1995) The insulin secretory response to intravenous glucose in the rat is independent of NO formation. Acta Physiol Scand 155: 61-65

24. Pueyo ME, Gonzalez W, Pussard E, Arnal JF (1994) Insulin secretion in rats with chronic nitric oxide synthase blockade. Diabetologia 37: 879-884

25. Jansson L, Sandler S (1991) The nitric oxide synthase II inhibitor NG-nitro-L-arginine stimulates pancreatic islet insulin release in vitro, but not in the perfused pancreas. Endocrinology 128: 3081-3085

26. Bult H, Boeckxstaens GE, Pelckmans PA, Jordaens FH, Van Maercke YM, Herman AG (1990) Nitric oxide as an inhibitory non-adrenergic non-cholinergic neutrotransmitter. Nature 345: 346-347

27. Moldovan S, Livingston E, Zhang RS, Kleinman R, Guth P, Brunicardi FC (1996) Glucose-induced islet hyperemia is mediated by nitric oxide. Am J Surg 171: 16-20

28. Gross R, Roye M, Manteghetti M, Hillaire Buys D, Ribes G (1995) Alterations of insulin response to different beta cell secretagogues and pancreatic vascular resistance induced by $\mathrm{N}$ omega-nitro-L-arginine methyl ester. $\mathrm{Br} \mathrm{J}$ Pharmacol 116: 1965-1972

29. Salehi A, Carlberg M, Henningson R, Lundquist I (1996) Islet constitutive nitric oxide synthase: biochemical determination and regulatory function. Am J Physiol 270: C1634-C1641

30. Drews G, Krippeit Drews P (1995) NO synthase activity does not influence electrical activity of mouse pancreatic B-cells. Biochem Biophys Res Commun 210: 914-920

31. Tasaka Y, Nakaya F, Matsumoto H, Omori Y (1994) Effects of aminoguanidine on insulin release from pancreatic islets. Endocr J 41: 309-313

32. Burrell MA, Montuenga LM, Garcia M, Villaro AC (1996) Detection of nitric oxide synthase (NOS) in somatostatinproducing cells of human and murine stomach and pancreas. J Histochem Cytochem 44: 339-346

33. Llewellyn Smith IJ, Song ZM, Costa M, Bredt DS, Snyder SH (1992) Ultrastructural localization of nitric oxide synthase immunoreactivity in guinea-pig enteric neurons. Brain Res 577: 337-342

34. Willmott N, Sethi JK, Walseth TF, Lee HC, White AM, Galione A (1996) Nitric oxide-induced mobilization of intracellular calcium via the cyclic ADP-ribose signaling pathway. J Biol Chem 271: 3699-3705

35. Schweizer M, Richter C (1994) Nitric oxide potently and reversibly de-energizes mitochondria at low oxygen tension. Biochem Biophys Res Commun 204: 169-175

36. Meffert MK, Calakos NC, Scheller RH, Schulman H (1996) Nitric oxide modulates synaptic vesicle docking fusion reactions. Neuron 16: 1229-1236

37. Manzoni O, Prezeau L, Marin P, Deshager S, Bockaert J, Fagni L (1992) Nitric oxide-induced blockade of NMDA receptors. Neuron 8: 653-662

38. Lei SZ, Pan ZH, Aggarwal SK, et al. (1992) Effect of nitric oxide production on the redox modulatory site of the NMDA receptor-channel complex. Neuron 8: 1087-1099

39. Lipton SA, Choi YB, Pan ZH, et al. (1993) A redox-based mechanism for the neuroprotective and neurodestructive effects of nitric oxide and related nitroso-compounds. Nature 364: 626-632

40. Manzoni O, Bockaert J (1993) Nitric oxide synthase activity endogenously modulates NMDA receptors. J Neurochem 61: 368-370

41. Akira T, Henry D, Wasterlain CG (1994) Nitric oxide mediates the sustained opening of NMDA receptor-gated ionic channels which follows transient excitotoxic exposure in hippocampal slices. Brain Res 652: 190-194 